\title{
1. Creating and conserving constitutional space
}

\author{
Paul T. Babie, Neville G. Rochow QC and \\ Brett G. Scharffs
}

\section{INTRODUCTION}

The year 2018 marked the 70th anniversary of the Universal Declaration on Human Rights ('UDHR'). ${ }^{1}$ Numerous events were held to mark the year with celebration and reflection, ${ }^{2}$ culminating with the Punta Del Este Declaration on Human Dignity for Everyone Everywhere on 5 December 2018, which, in commemorating the anniversary, 'celebrat[ed] its recognition of human dignity at the core of the panoply of human rights and recommit[ed] to protecting it for everyone everywhere'. ${ }^{3}$ The Punta Del Este Declaration represented 'the culmination of a series of conferences ... that explored the notion of human dignity, its relation to freedom of religion or belief, and the important role it has played in forming, guiding, and sustaining consensus on core human rights values despite tensions in a highly pluralized world' ${ }^{4}$ In its modest way, in the Australian context, the eponymous gathering described in our Acknowledgements contributed to this celebration, giving rise to discussions of the rights declared in the UDHR and the subjects explored in this volume,

1 UN General Assembly, Universal Declaration of Human Rights, 10 December 1948, 217 A (III).

2 See, e.g., Stand Up for Human Rights www.standup4humanrights.org/en/ index.html; 'Celebrate the 70th Anniversary of the UDHR', Amnesty International www.amnesty.org.au/events/celebrate-the-70th-anniversary-of-the-udhr/; 70 Years Universal Declaration of Human Rights www.humanrights70.eu.

3 Punta del Este Declaration on Human Dignity for Everyone Everywhere Introduction www.dignityforeveryone.org/introduction/.

${ }_{4}$ Punta del Este Declaration on Human Dignity for Everyone Everywhere Introduction www.dignityforeveryone.org/introduction/. 
and spawning an additional volume apart from this one, intended to promote awareness and discussion among general readers. ${ }^{5}$

In recent years, judicial and legislative developments the world over have sought to interpret the meaning of the protections for freedom of religion or belief ('FoRB') contained in Article 18 of the UDHR when those rights come into conflict with other fundamental rights, especially that of equality. Article 18 provides that 'Everyone has the right to freedom of thought, conscience and religion; this right includes freedom to change his religion or belief, and freedom, either alone or in community with others and in public or private, to manifest his religion or belief in teaching, practice, worship and observance'. Yet, the rights protected by FoRB, when implemented in domestic legal systems - usually in the form of constitutional provisions or legislative enactments - can come into conflict, in the public square, with other fundamental rights and freedoms. It is for that reason that Article 29, in part, reads:

(1) Everyone has duties to the community in which alone the free and full development of his personality is possible.

(2) In the exercise of his rights and freedoms, everyone shall be subject only to such limitations as are determined by law solely for the purpose of securing due recognition and respect for the rights and freedoms of others and of meeting the just requirements of morality, public order and the general welfare in a democratic society.

Moreover, not only is Article 29 frequently disregarded or given insufficient weight in religious freedom debates, but it is seldom recognised by those advocating freedom and governments implementing them that Article 18(3) of the International Covenant on Civil and Political Rights provides similar grounds for legitimate limitations on freedom to manifest one's religion or beliefs: 'Freedom to manifest one's religion or beliefs may be subject only to such limitations as are prescribed by law and are necessary to protect public safety, order, health or morals or the fundamental rights and freedoms of others.'

These matters are by no means straightforward. Nuances are evident from authoritative sources that have grappled with them. The Human Rights Committee has made extensive comments in its General Comment 22 The right to freedom of thought, conscience and religion as to how these rights and freedoms should be implemented and interpreted. ${ }^{6}$ The Siracusa Principles on the

5 Iain T Benson, Michael Quinlan and A Keith Thompson (eds), Religious Freedom in Australia: A New Terra Nullius? (Connor Court, 2019).

6 Human Rights Committee, General Comment 22, Article 18 (Forty-eighth session, 1993). Compilation of General Comments and General Recommendations Adopted by Human Rights Treaty Bodies, UN Doc. HRI/GEN/1/Rev.1 at 35 (1994). 
Limitation and Derogation Provisions in the International Covenant on Civil and Political Rights proffer guidance on drafting and proportionality in implementing limitations upon religious and conscientious freedoms. ${ }^{7}$ Unrestrained, rights to liberty of religion or conscience could give rise to acceptance of all sorts of damaging extremist conduct and cultist domination of individuals, ${ }^{8}$ with constitutional barriers often preventing state intervention. States must have appropriate mechanisms to prevent socially deleterious activity. ${ }^{9}$

Most often, it is some form of the protection provided for equality that comes up against the edges of FoRB. Throughout 2018 this conflict seemed more acute than ever. Indeed, judges in at least four jurisdictions were faced with mediating this conflict. In the European Union, for instance, the European Court of Justice in Egenberger v Evangelisches Werk für Diakonie und Entwicklung $\mathrm{eV}$ examined questions of autonomy for religious bodies from state scrutiny and judicial review, ${ }^{10}$ raising issues of proportionality and subsidiarity under the Allgemeines Gleichbehandlungsgesetz (the German general law on equal treatment), ${ }^{11}$ the European Union Equal Treatment Directive, ${ }^{12}$ the European Convention for the Protection of Human Rights and Fundamental Freedoms, ${ }^{13}$ the Treaty on European Union, ${ }^{14}$ and the Treaty on the Functioning of the European Union. ${ }^{15}$ At issue was whether the decision

7 Siracusa Principles on The Limitation and Derogation Provisions in The International Covenant on Civil and Political Rights American Association for The International Commission of Jurists.

8 See Steven Hassan, Freedom of Mind: Helping Loved Ones Leave Controlling People, Cults, and Beliefs (Freedom of Mind Press, 2012).

9 See Paul Babie and Joshua Neoh, 'A Statement on Inclusive Law and Religion' (2018) 39 Adelaide Law Review 203.

10 Vera Egenberger v Evangelisches Werk für Diakonie und Entwicklung eV [2018] EUECJ C-414/16. See also Opinion of Advocate General Tanchev, Case 414/16 (9 November 2017). See also 'Religion and the right to discriminate', Economist, 26 April 2018, www.economist.com/open-future/2018/05/24/freedom-of-speech-and-religion -is-not-a-licence-to-discriminate. See also Relu Adrian Coman, Robert Clabourn Hamilton, Asociaţia Accept v Inspectoratul General pentru Imigrări, Ministerul Afacerilor Intern, Case C-673/16 (ECJ); S.V. v Italy (no. 55216/08) (ECHR).

11 Allgemeines Gleichbehandlungsgesetz vom 14. August 2006 (BGB1. I S. 1897), das zuletzt durch Artikel 8 SEPA-Begleitgesetz vom 3. April 2013 (BGB1. I S. 610) geändert worden ist, para. $9(1)$.

12 Equal Treatment Directive 2000/78/EC, Article 4(2).

13 Council of Europe, European Convention for the Protection of Human Rights and Fundamental Freedoms, as amended by Protocols Nos. 11 and 14, 4 November 1950, ETS 5, arts 9, 10, 21, 22, and 47.

${ }_{14}$ European Union, Treaty on European Union (Consolidated Version), Treaty of Maastricht, 7 February 1992, Official Journal of the European Communities C 325/5; 24 December 2002, art 4(2).

15 Treaty on the Functioning of the European Union, Article 17. 
not to consider Egenberger's application for the advertised position, for which she was otherwise qualified, because of her lack of the appropriate religious affiliation could be reviewed for its necessity in the preservation of the employer's religious ethos. The decision of the European Court of Justice sought to define the nature of FoRB as a right to be developed case by case, requiring transparency, accountability and a requirement to demonstrate reasonableness in encroachments on the protections afforded equality.

In the United States, the Supreme Court of the United States had in 2012 endorsed the constitutional principle of Church autonomy from state control in Hosanna-Tabor Evangelical Lutheran Church and School $v$. Equal Employment Opportunity Commission, ${ }^{16}$ and in 2015, in Obergefell $v$. Hodges,${ }^{17}$ it found a constitutional right to same sex marriage, without addressing how conflicts between that right and freedom of religion would be adjudicated. The Hosanna-Tabor and Obergefell decisions set the background for the Court's major 2018 decision in Masterpiece Cakeshop, Ltd. v. Colorado Civil Rights Commission, ${ }^{18}$ in which the post-Obergefell balancing of rights and freedoms claimed by those who wish to discriminate on the basis of FoRB and those who object to being the subject of such discrimination is considered. ${ }^{19}$ In that case, the Supreme Court sidestepped the question of whether there is a free speech right to be free from coercion in expressing a message with which one disagrees, as well as the free exercise question of whether it is a violation of religious freedom to coerce a baker to make a cake celebrating a marriage he deems illegitimate. Instead, the Court focused on the manifest animus evidenced by the human rights commission in deciding against the baker, holding that such animus rendered the process of decision-making unconstitutional. Left for another day were the First Amendment speech and free exercise claims.

In Law Society of British Columbia v. Trinity Western University, ${ }^{20}$ and in Trinity Western University v. Law Society of Upper Canada, ${ }^{21}$ the Supreme Court of Canada considered the issue of proportionality and reasonableness on the part of a regulator, the Law Society of British Columbia, in its interference with the rights of a religiously affiliated educational body to require religious commitments from its students pursuant to the Canadian Charter of

\footnotetext{
16 Hosanna-Tabor Evangelical Lutheran Church and School v Equal Employment Opportunity Commission, 565 US 171 (2012).

17 Obergefell v. Hodges, 576 US _ (2015).

18 Masterpiece Cakeshop v Colorado Civil Rights Commission, 584 US (2018).

19 And see also State v Arlene's Flowers, Inc., P.3d (Wash. 2019).

20 Law Society of British Columbia $v$ Trinity Western University, 2018 SCC 32.

21 Trinity Western University v Law Society of Upper Canada, 2018 SCC 33.
} 
Rights and Freedoms. ${ }^{22}$ In that case, the Supreme Court conducted a judicial review of a decision by the Law Society of British Columbia (LSBC) not to accredit Trinity Western University law school ('TWU'). The law school had espoused an evangelical Christian ethos. As a part of that ethos, the law school required its students and faculty to agree to and abide by a code of conduct, the Community Covenant Agreement (Covenant). By the Covenant, students agree to abstain from 'sexual intimacy that violates the sacredness of marriage between a man and a woman'. Upon review, the majority of the Supreme Court held that the LSBC, under its enabling legislation in determining accreditation and consistent with Article 2(a) of the Charter, was right to consider TWU's admissions policies. It was entitled to do so in addition to considering the academic qualifications and competence of individual graduates. The majority held that, as a condition of admission, the Covenant imposed inequitable barriers to entry to the law school, consequently limiting diversity within the legal profession. And the Covenant, as a limitation, would have harmed LGBTQ individuals. The LSBC was entitled to form the view that these factors would have the consequence of diminishing the public interest in the administration of justice.

The Supreme Court of Canada also considered whether churches were decision-making bodies subject to judicial review for procedural fairness in Highwood Congregation of Jehovah's Witnesses (Judicial Committee) $v$. Wall, ${ }^{23}$ and lower appellate courts in Canada dealt with issues of FoRB as related to polygamy, ${ }^{24}$ and to religious education. ${ }^{25}$ Each of these cases dealt with the interaction of FoRB and equality pursuant to the Charter of Rights and Freedoms.

FoRB has been in a state of flux in the United Kingdom since the decision of the Supreme Court in Greater Glasgow Health Board v. Doogan, ${ }^{26}$ in which the right of medical practitioners not to participate in abortions was balanced against a requirement to refer patients to practitioners who would perform them. Because the United Kingdom does not have a defined concept of 'reasonable accommodation', the courts must develop incrementally the constitutional boundaries of FoRB. And this continues to be complicated

22 Canadian Charter of Rights and Freedoms, s 8, Part 1 of the Constitution Act, 1982, being Schedule B to the Canada Act 1982 (UK), 1982, c 11.

${ }^{23}$ Highwood Congregation of Jehovah's Witnesses (Judicial Committee) $v$ Wall [2018] 1 SCR 750.

${ }^{24}$ R. v Blackmore, 2018 BCSC 367.

25 Good Spirit School Division No. 204 v. Christ the Teacher Roman Catholic Separate School Division No. 212, 2017 SKQB 109. An appeal is currently pending before the Saskatchewan Court of Appeal.

26 Greater Glasgow Health Board v. Doogan \& Anor [2014] UKSC 68. 
by the anticipated consequences of Brexit for human rights in the United Kingdom, opening concerns about equality and non-discrimination currently protected by EU laws. ${ }^{27}$ Lee v. Ashers Baking Company Ltd, ${ }^{28}$ another recent decision of the UK Supreme Court, which considered Northern Ireland's antidiscrimination laws and famously revolved around the request for Christian bakers to provide pro-LGBT icing featuring Sesame Street characters Bert and Ernie, merely serves to demonstrate the difficulties of balancing FoRB against other fundamental freedoms in UK law. There the Supreme Court facilitated analytical clarity by explaining that the refusal was not discrimination against a same sex couple (it would not have mattered whether the buyer was gay or straight), but rather a conscience-based objection to communicating a message with which the bakery disagreed.

Finally, in Australia, while judicial development in 2018 was limited, interest in human rights generally and FoRB specifically was catalysed by a number of inquiries during that year, many of which had a significant impact on human rights and the way in which religion is regarded and is to be protected, or not protected. These included:

- The Royal Commission into Institutional Responses to Child Sexual Abuse (2013-17); ${ }^{29}$

- The RoyalCommission into Aged CareQuality and Safety(2018-ongoing); ${ }^{30}$

- The Human Rights and Technology Project; ${ }^{31}$ and

- The Senate Inquiry into Sex Discrimination Amendment (Removing Discrimination Against Students) Bill 2018. ${ }^{32}$

Each of these inquiries has, according to the respective terms of reference, either served to diminish confidence in institutions that were the subject of

27 See 'Human Rights Laws', Human Rights News, Views \& Info https://rightsinfo .org/brexit/human-rights-laws/.

${ }_{28}$ Lee v. Ashers Baking Company Ltd \& Ors [2018] UKSC 49. And see also In the matter of an application by the Northern Ireland Human Rights Commission for Judicial Review (Northern Ireland) [2018] UKSC 27.

29 See Australian Royal Commission into Institutional Responses to Child Sexual Abuse www.childabuseroyalcommission.gov.au.

30 See Australian Royal Commission into Aged Care Quality and Safety https:// agedcare.royalcommission.gov.au/Pages/default.aspx.

31 See Australian Human Rights Commission Human Rights and Technology Project www.humanrights.gov.au/our-work/rights-and-freedoms/projects/human-righ ts-and-technology.

32 See Parliament of Australia, Senate Standing Committees on Legal and Constitutional Affairs, Sex Discrimination Amendment (Removing Discrimination Against Students) Bill 2018 Inquiry www.aph.gov.au/Parliamentary_Business/ Committees/Senate/Legal_and_Constitutional_Affairs/Sexdiscrimination. 
the inquiry, or given confirmation that diminishing confidence was justified. ${ }^{33}$ In terms of potential impact upon religious freedom, the most significant has been the Royal Commission into Institutional Responses to Child Sexual Abuse. Institutions sponsored or run by the major denominations were the subject of horrific revelations of systemic child abuse and coverup that had gone virtually unchecked for decades. Among the final recommendations for governments and churches was a modification to the confidentiality of the confessional; ${ }^{34}$ those hearing confessions of child abuse would, if the reform were implemented, become mandatory reporters of child abuse. The response of governments was prompt and decisive in accepting that recommendation. ${ }^{35}$ The response of the churches requires some context.

Prior to and after publication of the Report, the Australian Catholic Church made its opposition to such a reform clear, thus setting up the quintessential conflict of religious dogma with the law. But the timing of that opposition and the manner of its expression were both unfortunate. Just months before the Commission reported in December 2017, in anticipation of its recommendation that reporting of child abuse discovered through the confessional become mandatory, prominent Catholic priest and legal academic Father Frank Brennan SJ wrote that, if the priest-penitent privilege or sacramental seal of the confessional were impinged, he would disobey the law and instead obey the law of the Church. ${ }^{36}$

\footnotetext{
33 See notes 29-32.

34 Summarised at www.childabuseroyalcommission.gov.au/sites/default/files/final report_-_recommendations.pdf, and see especially 50 et seq.

35 See, for example, 'Response to Child Abuse Royal Commission Recommendations', Attorney-General's Department Victoria, 11 July 2018, www .premier.vic.gov.au/response-to-child-abuse-royal-commission-recommendations/ ; South Australia, Department for Child Protection, 'South Australia's response to the Royal Commission into Institutional Responses to Child Sexual Abuse', www.childprotection.sa.gov.au/department/royal-commissions-and-reviews/royal -commission/south-australia-response; Elise Scott, 'ACT government agrees to all recommendations from child sex abuse royal commission', 15 June 2018, ABC News, www.abc.net.au/news/2018-06-15/act-to-implement-all-recommendations-from-royal -commission/9874288.

36 Frank Brennan, 'Frank Brennan: Why I will break the law rather than the seal of confession', 15 August 2017, The Sydney Morning Herald, www.smh.com.au/opinion/ frank-brennan-why-i-will-break-the-law-rather-than-the-seal-of-confession-20170815 -gxw7it.html:

If the law is changed, abolishing the seal of the confessional, I will conscientiously refuse to comply with the law because in good faith I will be able to claim that it is a bad law which does nothing to protect children and which may take away the one possibility that a sex offender will repent and turn himself in, making the world that little bit safer for vulnerable children.
} 
On 2 May 2018, after lengthy committal hearings, Cardinal George Pell, the highest ranking Australian Catholic prelate and third most highly ranking Catholic prelate in the world, was committed to stand trial relating to allegations of historical child abuse. Just weeks later, on 22 May 2018, Archbishop Philip Wilson, Archbishop of Adelaide, the most senior Catholic to be charged with a historical offence, was found guilty of concealment of child sexual abuse. On 15 June 2018, acting Catholic archbishop of the Adelaide Archdiocese, Bishop Kelly, said the proposed mandatory reporting law would not apply to the Catholic Church. On 4 July, 600 priests announced, by an open letter, that they would defy new laws that made reporting of child sex abuse mandatory. ${ }^{37}$

The Australian Catholic response drew attention in part because of Cardinal Pell's public profile - as one who had assisted in devising strategies to resist or limit legal claims brought by victims of abuse; as an opponent of the establishment of a Royal Commission that would investigate institutional abuse of children that included those operated by the Church; and as one of the leaders of the unsuccessful 'No' vote campaign in the postal survey debate in same sex marriage in the second half of 2017, on the strength of which Parliament amended the law of marriage. Even Archbishop Wilson's acquittal on appeal only served to divide the community further, especially for those who were or who sympathised with the victims of Catholic institutional abuse. Similar divisions arose upon Cardinal Pell's conviction and his subsequent unsuccessful appeal.

More significantly, in the 2017 debate leading up to the postal vote on the redefinition of marriage and since the changes to the law permitting same sex marriage, the 2018 Ruddock inquiry held in relation to FoRB sparked renewed interest in the potential for a federal freedom of religion act and a bill or charter of rights. ${ }^{38}$ Interest in the constitutional place of FoRB in Australian law, now piqued, is unlikely to wane in the near future. With the report of the Ruddock inquiry now a part of that context, ${ }^{39}$ and following the Israel Folau affair in

37 The Guardian, 'South Australia Catholic church to ignore law on reporting confessions of abuse', 15 June 2018, www.theguardian.com/world/2018/jun/15/south -australia-catholic-church-to-ignore-law-on-reporting-confessions-of-abuse: 'Acting Archbishop of the Adelaide Archdiocese, Bishop Greg Kelly is reported as saying, "Politicians can change the law, but we can't change the nature of the confessional, which is a sacred encounter between a penitent and someone seeking forgiveness and a priest representing Christ ... It doesn't affect us"'.

38 Paul Babie and Megan Lawson, 'The Law of Marriage Equality in Australia: The Shortest Distance Between Two Points?' (2017) 3 Interface Theology 1.

39 Religious Freedom Review: Report of the Expert Panel www.ag.gov.au/ RightsAndProtections/HumanRights/Documents/religious-freedom-review-expert -panel-report-2018.pdf. 
which the rugby star was sacked by Rugby Australia for his social media posts condemning 'sinners', including homosexuals, to hell unless they repented, ${ }^{40}$ political and constitutional debate as to the appropriate place of FoRB will only increase. While the Australian events represent a unique case, given the general lack of constitutional protection for human rights, including FoRB, the broad outlines of the issues - the interaction of equality and FoRB - remain the same as in many other jurisdictions.

\section{CONSTITUTIONAL SPACE}

What is demonstrated by the events of 2018 - the 70th anniversary commemorations of the UDHR and global legal developments, both judicial and legislative, concerning equality and FoRB - is the need to explore precisely what is meant by FoRB wherever that right is invoked, either as a matter of international or of domestic law. But more than this, what is necessary, now more than ever, is a careful analysis of the space available within any given legal system for conflicting rights to coexist in the public square, allowing for limitations to be placed both upon FoRB to the extent necessary for individuals to live and declare their ethos, and on those who would attempt to silence religion as an interlocutor in the public square. In other words, we need careful exploration of the points of contact, and conflict, between FoRB and other fundamental rights, especially equality and nondiscrimination. This book seeks to provide that analysis, examining the importance of a constitutionally protected right to FoRB as ensuring 'the conditions ... for investigation and pursuit of truth'. But more than this, it suggests that these conditions also make 'constitutional space' ${ }^{41}$ not only for FoRB, but also for competing fundamental rights and freedoms, and for the methods of balancing them when they come into conflict with one another. In other words, this book is about making 'constitutional space' for all fundamental rights and freedoms, FoRB among them.

As we use it here, 'constitutional space' serves as a metaphor for the convergence and confluence of constitutional powers which occurs in any legal system, as guided by principled approaches to the protection of rights. If not guided by principle, those powers collide at intersections, resulting in the loss or diminution of human rights and fundamental freedoms. Guided by

40 See Colette Langos and Paul Babie, 'Social Media, Free Speech, and Religious Freedom' Rutgers Journal of Law and Religion forthcoming.

${ }^{41}$ We borrow this term from Brett G Scharffs, 'Why Religious Freedom? Why the Religiously Committed, the Religiously Indifferent and Those Hostile to Religion Should Care' (2017) 2 Brigham Young University Law Review, who argues that liberal constitutional democracies must give "“constitutional space" for investigation and pursuit of truth.' 
principle, however, convergence creates greater space for all human rights and fundamental freedoms. And both the community and individuals thrive when that is the case. Principle is offended in respect of any right or freedom when it is given precedence over any other for reasons of political expediency. Thus, the principled exercise of legislative, executive and judicial powers comprises the essence of constitutional government, which in turn carves out a notional place or space where rights and freedoms reside in relation to one another. It is this that we mean by 'constitutional space'. Thus, constitutional space will create a framework for pluralism, a set of political and legal norms that create space for people and communities to work out their deeper moral and religious ways of living their lives.

This book explores the dimensions and contours of constitutional space, and how it can be made and sustained, within a given system, from both national and international perspectives. We do so in two parts. Part I of the book considers the dimensions and content of the concept of constitutional space for FoRB. In this part, Carolyn Evans argues that the appropriate mechanism for protection of freedom of religion is as part of a comprehensive bill or charter of rights. Chapters by Joel Harrison, Jeremey Patrick, Alex Deagon, Renae Barker, Joshua Forrester, Brett Scharffs, Neil Foster and Mark Fowler explore the content of 'reasonable accommodation', what is meant by 'religion' and what the right to 'freedom of religion' should contain.

Part II turns to the methods used in various countries to create and maintain the space for protection of FoRB within constitutional frameworks. This part includes chapters by Paul Taylor on Australia, Ping Xiong on China, Joshua Neoh on Malaysia, Ewelina Ochab on Iran, Arvind Bhanu on India, Mark Hill on the United Kingdom and the European Union and Vanja-Ivan Savić on Croatia.

\section{A 'WATCH LIST'}

As far as possible, we have endeavoured to adopt a broad scope in the topics covered in the volume, in concept and national experience. However, in candour, we, as editors, acknowledge some of the limitations we see in this book. First, its intended audience is generally that of the specialist in the field of human rights, with particular emphasis on freedoms of religion and conscience. Second, we have generally limited the scope to the events of and surrounding 2018, the 70th anniversary of the UDHR. It would not have been possible to finalise the volume with so many authors without these limitations. The second of those limitations has meant that events occurring in late 2018 and throughout 2019, significant though they might be, are not explored in the book. It is worthwhile, therefore, in partial remedy of these gaps, to provide 
a tentative watchlist for a few of these so that the interested reader can pursue them as they develop.

One significant development is that Lee v. Ashers Baking Company Ltd, ${ }^{42}$ mentioned above, ${ }^{43}$ is being appealed from the United Kingdom Supreme Court to the European Court of Human Rights in Strasbourg. ${ }^{44}$ The result of this appeal will likely determine whether and what differences exist between the approach to antidiscrimination laws under the First Amendment, as taken in the US Supreme Court decision in Masterpiece, ${ }^{45}$ and the European approach to similar laws under Article 9 of the European Convention on Human Rights. ${ }^{46}$

Another development is the continued interest in the concept of 'dignity' as an overarching concept to inform human rights and their implementation. ${ }^{47}$

42 Lee v. Ashers Baking Company Ltd \& Ors [2018] UKSC 49.

$43 \quad$ See note 27.

44 Henry McDonald, 'Gay marriage cake: customer takes case to European court', 15 August 2019, The Guardian, www.theguardian.com/uk-news/2019/aug/15/gay-ma rriage-cake-customer-takes-case-to-european-court.

45 Masterpiece Cakeshop v Colorado Civil Rights Commission, 584 U.S. (2018).

46 Which provides that:

Everyone has the right to freedom of thought, conscience and religion; this right includes freedom to change his religion or belief and freedom, either alone or in community with others and in public or private, to manifest his religion or belief, in worship, teaching, practice and observance.

Freedom to manifest one's religion or beliefs shall be subject only to such limitations as are prescribed by law and are necessary in a democratic society in the interests of public safety, for the protection of public order, health or morals, or for the protection of the rights and freedoms of others.

47 As examples only, there has developed a rich literature on the topic. See Aharon Barak, Human Dignity: The Constitutional Value and the Constitutional Right (Cambridge University Press, 2015) chs 3, 4 and 5; Mary Ann Glendon, 'The Bearable Lightness of Dignity' (May 2011) First Things www.google.com/url?q=https:// www.firstthings.com/article/2011/05/the-bearable-lightness-ofdignity\&sa=U\&ved $=$ 0ahUKEwig5bOls8zhAhWh7nMBHQw3A8MQFggUMAg\&client=internal-udscse \& $\mathrm{cx}=012931863361944243753: \mathrm{ft} 8$ sxapyb_o\&usg=AOvVaw1CWT6mDrX2pgeCvWD M4jX3; Jeremy Waldron, 'Is Dignity the Foundation of Human Rights?' in Rowan Cruft, S. Matthew Liao and Massimo Renzo (eds), Philosophical Foundations of Human Rights (Oxford University Press, 2015) ch 6; Jeremy Waldron, 'Dignity and Rank' (2007) 48 European Journal of Sociology 201; Michael Rosen, Dignity: Its History and Meaning (Harvard University Press, 2012); George Kateb, Human Dignity (Harvard University Press, 2011); Christopher McCrudden, 'Human Dignity in Human Rights Interpretation' (2008) 19 European Journal of International Law 655; Christopher McCrudden (ed), Understanding Human Dignity (Oxford University Press/British Academy, 2013); George Fletcher, 'Human Dignity as a Constitutional Value' (1984) 22 University of Western Ontario Law Review 178; Richard Rorty, Contingency, Irony and Solidarity (Cambridge University Press, 1989) 44-5 and 52-7; 
Apart from the previously mentioned Punta Del Este Declaration on Human Dignity for Everyone Everywhere in December of 2018, in 2019 there were academic conferences in Lucerne, Switzerland and Oxford, UK dedicated to the consideration of dignity as a topic. The recent interest taken in the concept by advocates of religious liberty might lead one to suspect that 'dignity' is being sought as a refuge from the losses suffered in the culture wars fought over liberty and equality.

However, a counterconsideration is that religious groups have long held to 'dignity' as central to dogmas, and did so well before the culture wars were even fought. The 1965 declaration on freedom of religion, made during the last phase of Second Vatican Council, Dignitatis humanae, ${ }^{48}$ opens with the words:

[a] sense of the dignity of the human person has been impressing itself more and more deeply on the consciousness of contemporary man, and the demand is increasingly made that men should act on their own judgment, enjoying and making use of a responsible freedom, not driven by coercion but motivated by a sense of duty. ${ }^{49}$

The Russian Orthodox Church echoed this sense of human dignity in its Basic Teaching on Human Dignity, Freedom and Rights, ${ }^{50}$ declaring that 'human rights theory is based on human dignity as its fundamental notion'. Similarly, the World Council of Churches has affirmed that it "works to defend human dignity by addressing human rights from an ethical and theological perspective'. The Islamic Network Group (ING) has likewise affirmed respect for human dignity in its First Principles of Religion, along with freedom of thought and expression, and respect for freedom of religion as fundamental to the religious beliefs of all major faiths. ${ }^{51}$

Moreover, the secular use of 'dignity' continues to dominate political and legal discourse. Francis Fukuyama, in keeping with the secular Kantian concept of dignity, has recently shown how 'dignity' and 'identity', free of any religious trappings, are central to Western political practice. ${ }^{52}$ In the 2019

Francis Fukuyama, Identity: The Demand for Dignity and the Politics of Resentment (Farrar, Straus and Giroux, 2018).

48 John W O'Malley, What Happened at Vatican II (Harvard University Press, 2008) $\mathrm{ch} 7$.

49 See the Holy See's website www.vatican.va/archive/hist_councils/ii_vatican _council/documents/vat-ii_decl_19651207_dignitatis-humanae_en.html.

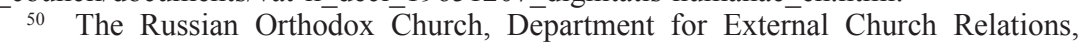
'Human dignity as religious and ethical category' https://mospat.ru/en/documents/ dignity-freedom-rights/i/.

${ }_{51}$ See First Principles of Religion: Human Dignity, Freedom of Expression, and Freedom of Religion https://ing.org/first-principles-religion-human-dignity-freedom -expression-freedom-religion/.

52 Fukuyama, above n 47. 
decision of the High Court of Australia, Clubb v. Edwards; Preston v. Avery, ${ }^{53}$ a statutory use of the concept of dignity was invoked to defeat asserted rights by antiabortionists to enter and proselytize within an abortion clinic access zone under the pretext of freedom of political communication. That implied constitutional freedom was held subject to a number of considerations, including the statutory preservation of the dignity of those entering the clinic. ${ }^{54}$ It would seem that the concept of 'dignity', both as a secular and as a religious principle, has some way to run. While it is difficult to see, in Australia at least, how religionists might appropriate the concept for any use beyond the secular, it will continue to be an area to watch.

Next in the watchlist is the concept of what William Galston refers to in his most recent book as 'tribal sentiments'. ${ }^{55}$ Galston regards this as one of the divisive manifestations of populism in Western culture. He describes these sentiments in these terms:

\begin{abstract}
Populism is unambiguously and unashamedly tribal. It legitimates sentiments that liberal democratic principles suppress. This is one of its main sources of strength. Tribes ascribe merit to their members and inferiority to non-members, usually in stereotypical terms. This gives rise to the remarkably stubborn phenomenon of prejudice. Even when members of a tribe are persuaded through reason and experience that their prejudice is unwarranted, the sentiment persists. Populist politicians understand this and appeal to their supporters by giving voice to views elites regard as beyond the pale, gleefully violating a norm known in the United States as 'political correctness.' When leaders breach these restraints, it produces a sense of release for their followers, much as comedy does. It also encourages people to imitate their leaders, with dangerous consequences for individual security and social order. In circumstances of scarcity or threat, the dyad of same and different gives way to the dyad of friends and enemies. ${ }^{56}$
\end{abstract}

The unfortunate consequences have been on full display in three events in Australia which typify the collapse of restraint when the tribe senses a loss. In each instance, the pitch of the fight has had religion as its focus. The first was the conviction, ${ }^{57}$ and subsequent unsuccessful appeal, ${ }^{58}$ of the world's third highest Catholic ranking prelate, Cardinal George Pell, on historic child

53 [2019] HCA 11.

54 Discussed in Neville Rochow QC and Jacqueline Rochow, 'From the Exception to the Rule: Dignity, Clubb v. Edwards, the Ruddock Review, and Religious Freedom as a Right' University of Western Australia Law Review 92.

55 William A Galston, Anti-Pluralism: The Populist Threat to Liberal Democracy (Politics and Culture) (Yale University Press, 2018) 132-3.

56 Ibid.

57 See www.countycourt.vic.gov.au/news-and-media/news-listing/2019-03-13-sen tencing-remarks-dpp-v-george-pell.

58 Pell v. The Queen, 2019 VSCA 186. 
sexual abuse charges. His supporters showed no compunction in criticizing the Australian judicial system as biased, prejudiced and manifestly unjust on the day his conviction was announced. Without any of the familiarity with the evidence that the jury possessed, it was labelled by this tribe as being a result of anti-Catholic prejudice and a product of a broken system. There could be no doubt that Pell had been a divisive figure, with many questioning his strategies on child abuse as being protective of the institution rather than showing any concern for the victims. But the outburst of criticism of a system was not warranted merely because the tribe's man had lost. Virtually the same disrespect was on display on delivery of the Court of Appeal decision to disallow the appeal; the only exception was that one of the three judges dissented from the majority rejection of the appeal. ${ }^{59}$ The vitriol was so intense and onesided that, in the eyes of many, it was the tribe rather than the system that lost credibility. Pell has announced that he will apply for leave to appeal to the High Court of Australia. But whether he is successful in that application and in any subsequent appeal, his tribe will, for those who consider that the Australian judicial system deserves better treatment than partisan barracking, remain ever tarnished and diminished. Nevertheless, it remains a case to watch.

Similar divisions surrounded the ongoing media spectacle of sports star Israel Folau, sacked for breach of contract by Rugby Australia for posting on social media a condemnation of 'sinners' - including drunks, adulterers and homosexuals - to hell unless they accepted his invitation to repent. Proceedings have now been filed in the Federal Circuit Court, likely to commence at trial in 2020. Folau is claiming damages of 10 million dollars, among other remedies. Despite its contractual and statutory basis, Folau's supporters almost universally regard this as a great landmark case for freedom of religious expression. The more sanguine regard it as an employment contract case. Controversially, with the assistance of the Australian Christian Lobby, Folau - who possesses assets understood to be personally worth several million dollars - raised by public appeal to his supporters more than two million dollars within two days, to assist him with legal fees.

One unfortunate aspect of the Folau controversy is that it came at a time when the federal government was considering its response to the Ruddock Expert Panel recommendation that there be Commonwealth freedom of religion legislation. The legislation is still in draft and the subject of public comment. The significant feature of the draft legislation architecture is to prohibit religious discrimination. The government has thus set its face against calls for a right to freedom of religion as either a standalone right or as a part of a bill or charter of rights. Apart from exposure to comment from the public, it has also yet to pass

59 Pell v. The Queen, 2019 VSCA 186 (Weinberg JA). 
through Parliament, not all members of which are convinced of the need for such legislation. The proposed legislative package was released on 29 August 2019, featuring as its centrepiece the Religious Discrimination Bill 2019 (Cth), which the government claims to provide comprehensive protection against discrimination on the basis of religious belief or activity. ${ }^{60}$ The same Bill, if passed, would establish a new office of Freedom of Religion Commissioner. ${ }^{61}$ This Bill purports to implement recommendations 15 and 19 of the Ruddock Report. ${ }^{62}$ The second Bill in the package is the Religious Discrimination (Consequential Amendments) Bill 2019 (Cth) which makes consequential amendments to existing Commonwealth legislation to support the introduction of the Religious Discrimination Bill. Third, the Human Rights Legislation Amendment (Freedom of Religion) Bill 2019 (Cth), if passed, would amend the Charities Act 2013 (Cth) and the Marriage Act 1961 (Cth) so as to provide certainty to charities and religious education institutions.

The coincidence in timing has made it difficult to discern just how much the drafting was influenced by the tribalism on display throughout the Folau media spectacle. There is at least one clause in the Religious Discrimination Bill which appears to have been directly influenced by the Folau controversy. ${ }^{63}$ It would seem that the draft legislation has pleased few and that each tribe has its own criticism. Those concerned about equality achieved under state legislation, particularly for LGBTIQ members of the community, fear that the new laws, if passed in their current form, would curtail the equality finally achieved after decades of hardfought reform. On the other side of the debate, conservative Christians in particular, who had been hoping that strong religious freedom laws would restore what they consider to be a lost balance between equality and liberty under antidiscrimination laws, argue that the proposed Bills do not go far enough to achieve that restoration. Another group disappointed with the Bills, predominantly conservative Catholics, had expected that there would be a positive right to freedom of religion and conscience. As an instance of populism attracting tribal sentiments, as described by Galston, how the Bills

${ }^{60}$ www.attorneygeneral.gov.au/Media/Pages/morrison-government-delivers -on-religious-reforms-29-august-2019.aspx?fbclid=IwAR1PizVI_iZLtVyV 6yE5id5UoAZPpUwTL35tbvfRONx6ojocwr_nsEkSETU.

${ }_{61}$ See above note 53.

62 See above note 53. The Ruddock Report is available at www.ag.gov.au/ RightsAndProtections/HumanRights/Documents/religious-freedom-review-expert -panel-report-2018.pdf.

${ }^{63}$ Clause 8(3) of the Religious Discrimination Bill 2019 (Cth). See Michelle Grattan, 'Religious Discrimination legislation would hit big companies harder than small business', 29 August 2019, The Conversation, https://theconversation.com/ religious-discrimination-legislation-would-hit-big-companies-harder-than-small -business-122623. 
progress through the public comment and Parliamentary processes should be on the watchlist. ${ }^{64}$

Finally, among gaps for the watchlist, there is a legitimate concern as to how human rights will fare in the face of economic and technological development. ${ }^{65}$ There has long been conservative resistance in Australia to the notion of a bill or charter of rights. ${ }^{66}$ This has meant that it is the only advanced Western democracy not to have a national constitutional or legislative collection of rights and freedoms. What has been missing in that debate to date is that the philosophical opposition to a bill or charter may no longer be a luxury that is affordable, as humans face the challenge of their rights and freedoms being eroded by supranational corporations and the advance of artificial intelligence. And this debate is by no means confined to Australia. Two recent Supreme Court decisions on the rights of American corporations - Citizens United $v$. Federal Election Commission, ${ }^{67}$ and Burwell v. Hobby Lobby ${ }^{68}$ - have raised the question as to whether corporations, as 'persons' but legal fictions nevertheless, should enjoy 'human' rights such as freedoms of speech and religion. ${ }^{69}$

64 On a possible way forward, see Sarah Moulds, 'Splitting the bill: How the feds could cut through division on religious freedom', Headlinez Pro, 16 September 2019, https://headlinezpro.com/splitting-the-bill-how-the-feds-could-cut-through-division -on-religious-freedom/.

65 See Neville Rochow QC, 'Somnambulating towards AI Dystopia? The Future of Rights and Freedoms' Interface Theology forthcoming; Neville Rochow QC, 'Immortal Beings Without Soul or Conscience: Toward a Corporate and an AI Ethic' in Paul Babie and Rick Sarre (eds), Bringing Religion to Life: The Contemporary Relevance of Religion (Springer, forthcoming).

${ }_{66}$ For the unique Australian context on this resistance to a bill or charter, see Carolyn Evans and Cate Read, 'Religious Freedom as an Element of the Human Rights Framework', Chapter 2 in this volume. For the broader constitutional, legislative, and political context, we commend the other chapters in the same part dealing with the unique Australian position: Joel Harrison, Chapter 3, 'The Problem and the Promise of Religious Liberty'; Jeremy Patrick, Chapter 4, "“A la Carte" Spirituality and the Future of Freedom of Religion'; Alex Deagon, Chapter 5, 'Towards a Constitutional Definition of Religion: Challenges and Prospects'; Renae Barker, Chapter 6, 'Freedom of Religion without a Bill of Rights: Australia's Peculiar Approach to Tackling Freedom of Religion and Other Human Rights Issues'; Joshua Forrester, Chapter 7, 'Conscience, Expression and the Commonwealth Constitution: The Effect of s 116 on the Implied Freedom of Political Communication'.

67558 US 310 (2010).

68573 U.S. (2014).

69 See, for example, Brett G Scharffs, 'Our Fractured Attitude towards Corporate Conscience' in Daniel N Robinson and Richard N Williams (eds), Religious Liberty Essays on First Amendment Law (Cambridge University Press, 2016) 125-64, available at https://doi.org/10.1017/CBO9781316556214.009 and the account given by Adam Winkler, We the Corporations - How American Business Won Their Civil Rights (Liveright, 2018). See also Michael Novak, Toward a Theology of the Corporation 
When trading corporations acquire sufficient market power, or, as Justice Brandeis once called it, 'the curse of bigness', they present a potential threat in preferring their own interest in pursuit of markets and more power. ${ }^{70}$ They do not, in any sense, behave as humans in the enjoyment of rights, but tend in general to pursue their own ends of profit and power. We should learn as much from our underestimations of international corporate power in relation to human rights abuses when dealing with the emerging power of information and $\mathrm{AI} .^{71}$ If human rights are not carefully articulated and entrenched while under human control of the rights agenda, how will they be protected as more power is ceded to corporations and algorithms? No universal legal or ethical regime governs research into or application of intelligent machine technology. This is despite initiatives by the United Nations and other international bodies. And yet use of that technology is universal in the developed world and its users are becoming increasingly dependent upon it. The technological advances are rapid, and adoption rates high, yet international and domestic regulation lags well behind. While at some governmental levels policymakers are now beginning to engage, the discussion is not broadranging enough. In particular, when it comes to human rights discourse, few appreciate the significance of failure to act. Failure to entrench human rights now, both constitutionally and technologically, will potentially result in first their diminution, and finally, their loss.

(American Enterprise Institute for Public Policy Research, 1981) and The Fire of Inventions - Civil Society and the Future of the Corporation (Rowman and Littlefield, 1999). See also Frank Ravitch, 'Be Careful What You Wish For: Why Hobby Lobby Weakens Religious Freedom' (2016) 55 Brigham Young University Law Review https://digitalcommons.law.byu.edu/lawreview/vol2016/iss1/6; and Frank Ravitch, Freedom's Edge: Religious Freedom, Sexual Freedom, and the Future of America (Cambridge University Press, 2016), ch 1.

70 Louis D. Brandeis, 'The Curse of Bigness' in Miscellaneous Papers of Louis D Brandeis (Osmond K. Fraenkel and Clarence M. Lewis, eds, Kennikat Press, 1965). See also Louis D. Brandeis, Other People's Money and How Bankers Use It (McLure Publications, 1914), cited in Timothy Wu, The Curse of Bigness: Antitrust in the New Gilded Age, (Columbia Global Reports, 2018) 15.

${ }^{71}$ John Gerard Ruggie, Just Business: Multinational Corporations and Human Rights (Norton \& Company, 2013). See also the principles developed by Ruggie and adopted by the United Nations Human Rights Council on 6 June 2011: www.business -humanrights.org/sites/default/files/reports-and-materials/Ruggie-protect-respect -remedy-framework.pdf; Business and Human Rights Centre, UN Secretary-General's Special Representative on Business \& Human Rights www.business-humanrights .org/en/un-secretary-generals-special-representative-on-business-human-rights; Surya Deva, 'Guiding Principles on Business and Human Rights: Implications for Companies' (2012) 9(2) European Company Law, pp.101-9, University of Oslo Faculty of Law Research Paper No 2012-10 https://papers.ssrn.com/sol3/papers.cfm ?abstract_id=2028785; Michael Sandel, What Money Can't Buy - The Moral Limits of Markets (Penguin, 2012) 65-70. 
With this introduction and the chapters that follow, it is our genuine hope that this volume makes a meaningful contribution to the ongoing discussion of how we might protect rights and freedoms domestically and internationally. We are indeed indebted to the authors of the respective chapters and their excellent contributions to these ongoing questions. Without their contributions, this volume would not have been possible. 